\title{
Soft Tissue Sarcoma of the Retroperitoneum Pathologic Regional Lymph Nodes TNM Finding v8
}

National Cancer Institute

\section{Source}

National Cancer Institute. Soft Tissue Sarcoma of the Retroperitoneum Pathologic

Regional Lymph Nodes TNM Finding v8. NCI Thesaurus. Code C136808.

A pathologic finding about one or more characteristics of soft tissue sarcoma of the retroperitoneum, following the rules of the TNM AJCC v8 classification system as they pertain to staging of regional lymph nodes. 